\title{
ANALISIS PENDAPATAN USAHATANI SAYURAN SAWI (Brassica rapa var. Parachinensis L.) DI KELURAHAN KALAMPANGAN KECAMATAN SABANGAU KOTA PALANGKA RAYA
}

\author{
${ }^{1}$ Baktiar Josua, ${ }^{2}$ Revi Sunaryati, ${ }^{3}$ Masliani
}

\author{
${ }^{1}$ Alumnus Program Studi Agribisnis Fakultas Pertanian Universitas Palangka Raya \\ ${ }^{23}$ Staf Pengajar Program Studi Agribisnis Fakultas Pertanian Universitas Palangka Raya
}

\begin{abstract}
ABSTRAK
Sayuran Sawi (Brassica rapa var. Parachinensis L.) merupakan tanaman hortikultura dari jenis sayuran dimana bagian yang dimanfaatkan adalah daun-daun yang masih muda. Layaknya jenis sayuran lainnya, sawi juga memiliki berbagai macam manfaat dan kegunaan untuk kesehatan manusiawi. Sawi selain dimanfaatkan sebagai bahan makanan sayuran, juga dapat dimanfaatkan untuk pengobatan. Sawi termasuk sayuran daun dari keluarga Crucifeae yang mempunyai nilai ekonomi yang tinggi. Usahatani sayuran sawi dibudidayakan setiap tahunnya karena komoditas sayur sawi ini merupakan tanaman hortikultura yang menunjang perekonomian petani dengan masa tanaman yang cepat dan prospek kedepannya yang cukup menjanjikan dalam memberikan sumbangan pendapatan kepada petani di Kelurahan Kalampangan. Hasil penelitian menunjukkan bahwa rata-rata pendapatan usahatani sayuran sawi per satu kali musim tanam adalah sebesar Rp 754.523/petani $/ \mathrm{m}^{2}$ dengan nilai rata-rata jumlah penerimaan sebesar $\mathrm{Rp}$ $1.249 .750 /$ petani $/ \mathrm{m}^{2}$ dan nilai rata-rata biaya yang dikeluarkan terdiri dari biaya tetap dan biaya variabel. Biaya tetap terdiri dari penyusutan alat sebesar Rp 327.627, sedangkan biaya variabel sebesar Rp.167.601 terdiri dari biaya benih sebesar Rp 27.200, biaya pupuk Urea Rp 6.617, biaya pupuk Phonska Rp 9.117, biaya pupuk NPK Mutiara Rp 30.667, biaya pestisida Rp 70.667 dan tenaga kerja Rp 23.333. Tingkat efisiensi usahatani sayuran sawi di Kelurahan Kalampangan adalah sebesar 2,52 artinya usahatani tersebut layak untuk dijalankan kembali dan menguntungkan karena penerimaannya lebih besar dari biaya yang dikeluarkan.
\end{abstract}

Kata Kunci : Sayuran Sawi, Pendapatan dan Efisiensi atau RCR

\section{ABSTRACT}

Mustard greens (Brassica rapa var. Parachinensis L.) is a horticultural crop of vegetable species in which the parts used are young leaves. Like other types of vegetables, mustard greens also have a variety of benefits and uses for human health. Apart from being used as vegetable food, it can also be used for treatment. Mustard is a leaf vegetable from the Crucifeae family which has high economic value. Mustard vegetable farming is cultivated every year because this mustard vegetable commodity is a horticultural crop that supports the farmers' economy with a fast crop period and the prospects for the future is quite promising in contributing income to farmers in the Kalampangan Village. The results showed that the average income of mustard vegetable farming per planting season was Rp 754.523 / farmer $/ \mathrm{m}^{2}$ with an average value of income of $\mathrm{Rp} 1.249 .750 /$ farmer $/ \mathrm{m}^{2}$ and the average 
value of costs incurred consisted of fixed costs and variable costs. Fixed costs consist of depreciation of equipment amounting to Rp 327.627, while variable costs of $\mathrm{Rp} 167.601$ consist of seed costs of $\mathrm{Rp} 27.200$, Urea fertilizer costs Rp 6.617, Phonska fertilizer costs Rp 9.117, NPK Mutiara fertilizer costs Rp 30.667, pesticides costs Rp 70.667 and labor cost Rp 23.333. The level of efficiency or RCR of mustard vegetable farming in the village of Kalampangan is 2,52 meaning that the farm is feasible to run again and is profitable because its revenue is greater than the costs incurred.

\section{Keywords: Mustard greens, Income and Efficiency or RCR ratio}

\section{PENDAHULUAN \\ Latar Belakang}

Kelurahan Kalampangan mayoritas penduduknya berprofesi sebagai petani. Usahatani sayuran sawi manis atau sawi caisim dibudidayakan setiap tahunnya karena komoditas sawi ini merupakan tanaman hortikultura yang menunjang perekonomian petani dengan masa tanam yang cepat dan prospek kedepannya yang cukup menjanjikan dalam memberikan sumbangan pendapatan kepada petani di Kelurahan Kalampangan. Sumbangan pendapatan yang diperoleh dapat di lihat pada hasil akhir produksi yang memuaskan serta adanya harga jual yang sesuai. Keberhasilan petani dalam usahatani sawi yang dihasilkan tidak terjadi secara terus menerus hal ini dikarenakan adanya beberapa kendala di wilayah tersebut (BPP Kalampangan, 2016).

Keadaan ini disebabkan adanya perubahan cuaca atau iklim yang merupakan salah satu faktor yang berpengaruh terhadap usahatani sayuran sawi di Kelurahan Kalampangan. Perubahan cuaca atau iklim yang menyebabkan harga sawi menjadi tidak stabil ataupun rendah di pasar dan mengakibatkan petani sulit untuk menjualnya ke pasar, sehingga sayuran sawi yang sudah waktunya panen akan dibiarkan di ladang ataupun dibagikan kepada para tetangga di lingkungan sekitar.
Ini merupakan salah satu bentuk atau upaya yang dilakukan oleh petani. Apalagi sifat umum dari tanaman hortikultura ini mudah rusak sehingga membuat para petani semakin menjaga pemeliharaan tanaman sawi. Meskipun harga tanaman sawi tidak stabil di pasar akan tetapi petani tetap melakukan usahatani sawi karena sayuran sawi merupakan tanaman yang sangat dibutuhkan bagi masyarakat yaitu sebagai sumber vitamin dan banyak mengandung bahan-bahan yang dibutuhkan oleh tubuh (BPP Kalampangan, 2016).

Usahatani sayuran sawi diharapkan mampu memberikan sumbangan yang cukup besar bagi peningkatan pendapatan dan kesejahteraan bagi petani sayuran sawi di Kelurahan Kalampangan Kecamatan Sabangau Kota Palangka Raya. Hingga saat ini usahatani sayuran tersebut masih terus berjalan sebagai salah satu mata pencaharian utama bagi petani di Kelurahan Kalampangan. Adanya kondisi harga jual sayuran sawi yang saat ini dirasakan sering mengalami fluktuatif dan tidak stabil oleh para petani menyebabkan keresahan sendiri dalam menjalankan usahataninya tersebut. Hal ini disebabkan karena dalam menjalankan usahanya, para petani sayuran sawi di Kelurahan Kalampangan memperhitungkan mengenai masalah biaya dan keuntungan yang diperolehnya. Mereka berharap dari hasil usahataninya tersebut memperoleh keuntungan seoptimal mungkin dengan biaya yang seminimal 
mungkin sehingga dapat digunakan untuk memenuhi kehidupan keluarganya seharihari (BPP Kalampangan, 2016).

\section{Tujuan Penelitian}

Tujuan dari penelitian ini adalah sebagai berikut:

1. Mengetahui keragaan usahatani sayuran sawi di Kelurahan Kalampangan, Kecamatan Sabangau, Kota Palangka Raya.

2. Menganalisis tingkat penerimaan, biaya dan pendapatan petani sayuran sawi di Kelurahan Kalampangan, Kecamatan Sabangau, Kota Palangka Raya.

3. Menganalisis tingkat efisiensi usahatani sayuran sawi di Kelurahan Kalampangan, Kecamatan Sabangau, Kota Palangka Raya.

\section{TINJAUAN PUSTAKA \\ Tanaman Sawi}

Sayuran Sawi (Brassica rapa var.

Parachinensis L.) merupakan tanaman hortikultura dari jenis sayuran dimana yang bagian dimanfaatkan adalah daun daun yang masih muda. Sawi juga memiliki berbagai macam manfaat dan kegunaan untuk kesehatan manusiawi. Tanaman sawi selain dimanfaatkan sebagai bahan makanan sayuran, juga dapat dimanfaatkan untuk pengobatan. Sawi termasuk sayuran daun dari keluarga Crucifeae yang mempunyai nilai ekonomi yang tinggi (Putri, 2016).

Menurut sejarahnya, sawi juga diperkirakan berasal dari kawasan Mediterania dan daerah Timur dekat Afganistan, Iran, dan Pakistan Barat. Adapun bukti lain menunjukkan bahwa tanaman ini berasal dari Cina dan Asia bagian Timur. Oleh karena itu, hingga kini banyak dijumpai berbagai jenis sawi sayng sangat berbeda dari induknya. Termasuk dalam grup Pekinensis diantaranya pe-tsai atau bok choy, dan grup Chinensis adalah choy sum atau caisim atau sawi bakso dan pak choy (Zulkarnain, 2013).

Petani di Kelurahan Kalampangan umumnya menanam sayuran sawi (Brassica rapa var. Parachinensis yang disebut juga sawi bakso, chaisim, atau chaisin). Sayuran sawi dapat ditanam di dataran tinggi maupun dataran rendah. Akan tetapi, umumnya sawi diusahakan di dataran rendah, yaitu di pekarangan, di ladang, di pot atau di sawah, jarang diusahakan di daerah pegunungan. Sayuran sawi termasuk tanaman sayuran yang tahan terhadap hujan. Sehingga sawi dapat ditanam di sepanjang tahun, asalkan pada saat musim kemarau disediakan air yang cukup untuk penyiraman.

\section{Teori Usahatani}

Prasetya (2006) menyatakan usahatani adalah ilmu yang mempelajari norma-norma yang dapat dipergunakan untuk mengatur usahatani sedemikian rupa sehingga dapat diperoleh pendapatan setinggi-tingginya.

Menurut Suratiyah

mendefinisikan bahwa usahatani sebagai ilmu yang mempelajari bagaimana seseorang mengusahakan dan mengkoordinir faktor-faktor produksi berupa lahan dan alam sekitarnya sebagai modal sehingga memberikan manfaat yang sebaik-baiknya. Usahatani merupakan caracara menentukan, mengorganisasikan dan mengkoordinasi penggunaan faktor-faktor produksi seefektif dan seefisien mungkin sehingga usaha tersebut memberikan pendapatan semaksimal mungkin. Faktor produksi dalam usahatani terdiri dari empat unsur pokok. Empat unsur pokok tersebut yaitu tanah, tenaga kerja, modal, dan pengelolaan atau manajemen.

Ilmu usahatani menurut Soekartawi (2006) adalah ilmu yang mempelajari bagaimana seseorang mengalokasikan sumberdaya yang ada secara efektif dan efisien untuk memperoleh keuntungan yang tinggi pada waktu tertentu. Usahatani dapat dikatakan efektif bila petani dapat mengalokasikan sumberdaya yang dimiliki dengan sebaik-baiknya, dan dikatakan efisien bila pemanfaatan sumberdaya tersebut menghasilkan keluaran (output) yang melebihi masukan (input) 


\section{METODE PENELITIAN Tempat dan Waktu Penelitian}

Penelitian ini dilaksanakan di Kelurahan Kalampangan, Kecamatan Sabangau, Kota Palangka Raya, Provinsi Kalimantan Tengah. Lokasi penelitian ditentukan secara purposive yaitu penentuan lokasi yang berdasarkan dengan kriteria-kriteria tertentu yang ditetapkan berdasarkan tujuan penelitian (Sugiyono, 2008). Kelurahan Kalampangan dipilih secara purposive (sengaja) untuk lokasi penelitian dikarenakan daerah penelitian ini merupakan salah satu sentra usahatani tanaman sayuran sawi di Kecamatan Sabangau.

Penelitian ini dilaksanakan selama 3 (tiga) bulan, yaitu terhitung sejak bulan Agustus sampai dengan Oktober 2019. Dari tahap pengumpulan data di lapangan, pengolahan pembuatan proposal penelitian sampai dengan hasil penelitian.

\section{Populasi dan Sampel}

Penelitian ini dilakukan dengan menggunakan metode survei. Metode Survei adalah penelitian yang mengambil sampel dari satu populasi dan menggunakan kuesioner sebagai alat pengumpulan data yang pokok (Singarimbun dan Effendi, 2008). Sampel adalah bagian dari jumlah dan karakteristik yang dimiliki oleh populasi tersebut. Dengan demikian sampel adalah sebagian dari populasi yang karakteristiknya hendak diselidiki, dan bisa mewakili keseluruhan populasinya sehingga jumlahnya lebih sedikit dari populasi.

Tiap anggota populasi yaitu setiap kepala keluarga (KK) atau keluarga petani sayuran sawi di Kelurahan Kalampangan yang memiliki kesempatan sama untuk diambil sebagai sampel. Pengambilan sampel menggunakan metode Terstratifikasi (Proportionate Stratified Proporsional Sampling) yaitu populasi dikelompokkan menjadi sub-sub populasi secara bergerombol (cluster). Dari sub populasi selanjutnya dirinci lagi menjadi subpopulasi yang lebih kecil dan anggota dari sub populasi terakhir dipilih secara acak sebagai sampel penelitian.

Dari 5 RW yang ada di kelurahan Kalampangan dipilih secara sengaja (purposive) yaitu RW.03 sebagai tempat penelitian dengan jumlah populasi sebanyak $236 \mathrm{KK}$ dan memiliki RT sebanyak 6 RT agar dapat memudahkan peneliti dalam melakukan penelitian.

Dari masing-masing RT yang ada lalu di ambil sampel menggunakan rumus Terstratifikasi

(Proporsionate Stratified Random Sampling) yaitu sebagai berikut :

$$
\mathrm{n}=\frac{\mathrm{Ni}}{\mathrm{N}} \times \mathrm{d}
$$

Keterangan :

$\mathrm{n}$ = Banyaknya anggota yang dimasukkan menjadi sampel

$\mathrm{Ni}=$ Jumlah populasi KK dari setiap RT

$\mathrm{N}$ = Jumlah populasi seluruhnya

$\mathrm{d} \quad=$ Jumlah sampel yang ditentukan

Dengan perhitungan sebagai berikut :

1. $R T 1=\frac{37}{236} \times 30=4,70 \quad$ terambil 5 sampel

2. $R T 2=\frac{45}{236} \times 30=5,72$ terambil 6 sampel

3. $R T 3=\frac{49}{236} \times 30=6,22$ terambil 6 sampel

4. $R T 4=\frac{42}{236} \times 30=5,33$ terambil 5 sampel

5. $R T 5=\frac{38}{236} \times 30=4,83$ terambil 5 sampel

6. $R T 6=\frac{25}{236} \times 30=3,17$ terambil 3 sampel

Jadi dari 6 RT yang ada pada RW.03 maka diambil 30 petani sawi dengan pertimbangan bahwa jumlah sampel sebanyak 30 petani tersebut sudah memenuhi kriteria sampel besar yang 
diperkirakan sudah memenuhi persyaratan penyebaran normal (Soekartawi, 2006).

\section{Pengumpulan Data}

Menurut Sugiyono (2013), jika di lihat dari segi cara atau teknik pengumpulan data, maka teknik pengumpulan data dapat dilakukan dengan cara interview (wawancara) dan observasi (pengamatan). Metode pengumpulan data menggunakan data primer dan data sekunder. Data yang diperlukan dalam penelitian ini adalah sebagai berikut :

1. Data Primer

Data primer yang dikumpulkan menggunakan metode survei, yaitu mengumpulkan informasi data yang diperlukan untuk penelitian ini dengan cara wawancara langsung kepada responden. Kegiatan wawancara ini dibantu dengan kuesioner berupa daftar pertanyaan yang sudah disusun oleh peneliti. Hal ini dilakukan agar kegiatan wawancara berlangsung efektif dan sesuai dengan tujuan pengumpulan data primer tersebut. Data primer yang diperlukan meliputi daftar pertanyaan mengenai biaya usahatani yang dikeluarkan, sumber penerimaan dari apa saja baik dari usahatani maupun luar usahatani. Data primer biasanya diperoleh melalui pengambilan data secara langsung yaitu dari para petani sayuran sawi di Kelurahan Kalampangan Kecamatan Sabangau dengan menggunakan kuesioner berisi data tentang identitas responden, luas lahan, penggunaan pupuk, tenaga kerja dan pestisida pada usahatani sayuran sawi di Kelurahan Kalampangan.

2. Data Sekunder

Data sekunder yang dipergunakan dalam penelitian ini bersumber dari instansi-instansi atau dinas yang terkait dengan penelitian ini seperti Badan Pusat Statistik Kota Palangka Raya, Dinas Ketahanan Pangan dan Pertanian Kota Palangka Raya, Kelurahan Kalampangan, Kecamatan Sabangau, Balai Penyuluhan Pertanian dan Peternakan Kelurahan Kalampangan, publikasi dari penelitian yang sudah dilakukan sebelumnya serta dari pustaka lainnya yang berhubungan dengan penelitian ini. Data sekunder yang dibutuhkan dari instansi yang terkait yaitu mengenai jumlah produksi, luas panen, produktivitas tanaman sayuran sawi, keadaan umum daerah lokasi penelitian, monografi kecamatan, dan data-data lain yang berhubungan dengan penelitian ini.

\section{Metode Analisis Data}

Metode analisis yang digunakan dalam penelitian ini adalah data dari hasil penelitian diedit dan diolah dalam bentuk tabulasi (tabel) yang kemudian dilakukan dengan alat hitung (kalkulator) dan bantuan (komputer) dengan software atau program aplikasi Microsoft Excel, kemudian pengumpulan data dilakukan dengan pengisian kuesioner dari petani responden. Selain itu juga dilakukan pengumpulan data dari Dinas Ketahanan Pangan dan Pertanian Kota Palangka Raya, Kelurahan Kalampangan dan Balai Penyuluhan Pertanian dan Peternakan Kelurahan Kalampangan. Sedangkan untuk pengamatan (observasi) dilapangan dilakukan secara deskriftif yaitu dari hasil pengamatan yang diperoleh diuraikan dalam bentuk kalimat untuk memberikan penjelasan mengenai topik yang dibahas.

1. Untuk menjawab tujuan pertama dari penelitian ini yaitu mengetahui keragaan usahatani sayuran sawi di Kelurahan Kalampangan, Kecamatan Sabangau, Kota Palangka Raya

2. Untuk menjawab tujuan kedua dari penelitian ini yaitu menganalisis tingkat penerimaan, biaya dan pendapatan petani sayuran sawi. Untuk mengetahui total biaya dalam usahatani sayuran sawi menggunakan rumus sebagai berikut:

a. Penerimaan Total Usahatani Sayuran Sawi $(T R)$

$$
T R=\mathrm{Yi} . \mathrm{Pyi}
$$

Keterangan :

$T R=$ Total Penerimaan Usahatani Sayuran Sawi atau $(\mathrm{Rp})$ 


$$
\begin{aligned}
\mathrm{Yi}= & \text { Jumlah Produksi Sayuran Sawi } \\
& (\text { Ikat }) \\
\text { Pyi }= & \text { Harga Produksi Sayuran Sawi } \\
& (\text { Rp/lkat }) \\
\mathrm{i} \quad= & 1,2,3, \ldots \mathrm{n}
\end{aligned}
$$

Sementara itu, untuk mengetahui total biaya dari usahatani sayuran sawi menggunakan rumus sebagai berikut:

b. Biaya Total Usahatani Sayuran Sawi (TC)

$$
T C=F C+V C
$$

Keterangan:

$$
\begin{aligned}
T C= & \text { Biaya Total Usahatani Sayuran } \\
& \text { Sawi atau Total Cost }(\mathrm{Rp}) \\
F C= & \text { Biaya Tetap Usahatani Sayuran } \\
& \text { Sawi atau Fixed Cost }(\mathrm{Rp}) \\
V C= & \text { Biaya Variabel Usahatani } \\
& \text { Sayuran Sawi atau Variable } \\
& \text { Cost }(\mathrm{Rp})
\end{aligned}
$$

Setelah mengetahui jumlah total biaya dan total penerimaan usahatani sayuran sawi, maka selanjutnya dapat diketahui pendapatan usahatani sayuran sawi dengan menggunakan rumus sebagai berikut :

c. Pendapatan Usahatani Sayuran Sawi (I)

$$
I=T R-T C
$$

Keterangan :

$I$ = Pendapatan Usahatani Sayuran

Sawi atau Income (Rp)

$T R=$ Total Penerimaan atau Total Revenue (Rp)

$T C=$ Biaya Total atau Total cost $(\mathrm{Rp})$

Kriteria pengambilan keputusan sebagai berikut :

- Jika $I>0$, maka usahatani sayuran sawi menguntugkan

- Jika $I=0$, maka usahatani sayuran sawi berada pada titik impas

- Jika $I<0$, maka usahatani sayuran sawi merugikan

3. Untuk menjawab tujuan ketiga dari penelitian ini yaitu mengetahui tingkat efisiensi usahatani sayuran sawi. Tingkat efisiensi adalah untuk menganalisis perbandingan (nisbah) antara total penerimaan $(T R)$ dan total biaya (TC). Pengolahan dan analisis data dalam penelitian ini dapat diuraikan sebagai berikut:

$$
\begin{gathered}
R C R=\frac{T R}{T C} \\
R C R=\frac{\mathrm{Yi} \cdot \mathrm{Pyi}}{F C+V C}
\end{gathered}
$$

Keterangan:

$R C R=$ Revenue Cost Ratio

$T R=$ Penerimaan Total Usahatani Sayuran Sawi atau (Rp)

$T C=$ Biaya Total Usahatani Sayuran Sawi atau Total Cost (Rp)

Yi = Jumlah Produksi Sayuran Sawi (Ikat)

Pyi = Harga Produksi Sayuran Sawi (Rp/Ikat)

$F C=$ Biaya Tetap Usahatani Sayuran Sawi atau Fixed Cost (Rp)

$V C=$ Biaya Variabel Usahatani Sayuran Sawi atau Variable Cost $(\mathrm{Rp})$

$\mathrm{i}=1,2,3, \ldots \mathrm{n}$

$R / C$ Rasio mengambarkan tingkat keuntungan usahatani, semakin tinggi $R / C$ Rasio maka semakin besar keuntungan suatu usahatani. Untuk lebih jelasnya dapat dilihat tingkat keuntungan $R / C$ Rasio sebagai berikut:

$R / C=1$ Berarti usahatani sayuran sawi yang dijalankan tersebut dalam keadaan impas, dimana nilai biaya sama dengan nilai penerimaan $(T R=T C)$.

$R / C<1$ Berarti usahatani sayuran sawi yang dijalankan tersebut tidak menguntungkan atau rugi, karena biaya lebih besar daripada penerimaan $(T R<T C)$.

$R / C>1$ Berarti usahatani sayuran sawi yang dijalankan tersebut menguntungkan, karena penerimaan lebih besar dari biaya $(T R>T C)$.

HASIL DAN PEMBAHASAN Aspek Teknis Usahatani Sayuran Sawi 
Sayuran Sawi yang diusahakan oleh ke 30 petani sawi tersebut adalah jenis sawi hijau (Brassica rapa var. Parachinencis L. yang disebut juga sawi bakso, caisim, atau caisin). Alasan petani memilih varietas sawi hijau karena pemeliharaannya cukup mudah dan masa panennya yang cepat sehingga petani tidak terlalu lama menunggu untuk memetik hasilnya.

\section{Persiapan Lahan}

Persiapan lahan yang dilakukan oleh petani di Kelurahan Kalampangan ialah membersihkan lahan dari rumput atau gulma, pencangkulan, penggemburan tanah pembuatan irigasi dan menaburkan abu rumput maupun pupuk kandang seacara merata ke lahan tersebut. Hal ini dilakukan untuk menyuburkan tanah.

\section{Penanaman}

Penanaman dilakukan pada waktu pagi atau sore hari, hal ini bertujuan agar keadaan tanah tetap lembab. Sebelum di tanam, benih sawi disemai terlebih dahulu selama 21-25 hari dan baru bibit bisa dipindah ke lahan tempat sawi. Adapun benih yang digunakan oleh 30 petani sayuran sawi tersebut adalah benih sawi hijau, benih-benih tersebut juga mudah didapatkan biasanya petani sawi menggunakan merek benih sawi cap panah merah. Cara penanaman yang dilakukan oleh ke 30 petani sayuran sawi tersebut yaitu dengan cara terlebih dahulu lahan ditugal dengan kedalaman $1,5 \mathrm{~cm}$ dengan jarak tanam 40 × $40 \mathrm{~cm}$ antar barisan tanam. Penanaman sawi bisa saja dilakukan dengan penanaman secara langsung dengan benih tanpa melakukan proses penyemaian atau dengan bibit dimana benih yang sudah melalui proses persemaian terlebih dahulu. Setiap lubang tanam berisi 2-3 benih sawi untuk nantinya hanya satu bibit yang sehat dan kuat saja yang dibiarkan tumbuh hingga dewasa, sedangkan sisanya dibuang atau ditanam pada lahan lain.

\section{Pemeliharaan}

Pemeliharaan atau perawatan tanaman sawi diantaranya penyiangan dilakukan setelah melihat pertumbuhan gulma. Penyiangan biasanya dilakukan sebanyak 2-4 kali selama masa tanam yang dimulai umur 1-2 minggu setelah tanam dan dilakukan pula penggemburan tanah dan perbaikan drainase secara bersamaan.

Penyiraman atau pengairan dilakukan dengan melihat keadaan cuaca dan iklim. Di musim penghujan pemberian air hanya sesekali saja atau dibatasi dan perlu melakukan perbaikan saluran drainase. Sebaliknya di musim kemarau lahan perlu diairi secara memadai untuk mencukupi kebutuhan tanaman. Apabila hari tidak terlalu panas maka petani sawi menyiramnya sekali sehari, pagi atau sore hari.

\section{Pemupukan}

Pemberian pupuk dilakukan sebagai tambahan setelah bibit disemaikan. Jenis pupuk yang digunakan oleh petani tersebut adalah pupuk Urea, pupuk NPK Phonska, pupuk NPK Mutiara 16-16-16 dan juga pupuk kandang. Rata-rata petani menggunakan pupuk untuk area tanam 30 $\mathrm{m}^{2}$ adalah pupuk Urea dengan rata-rata petani menggunakan $2,17 \mathrm{Kg}$, pupuk Phonska 2,30 Kg dan pupuk NPK Mutiara $3,80 \mathrm{Kg}$.

\section{Panen dan Pasca Panen}

Cara panen sayuran sawi yang dilakukan oleh petani di Kelurahan Kalampangan yaitu dengan cara memotong pangkal batang sawi menggunakan pisau, mencabut seluruh tanaman, atau memetik daunnya satu per satu.

Setelah dipanen, para petani sesegera mungkin membawa hasil panen ke tempat teduh untuk menghindari sawi cepat layu karena sinar matahari. Selanjutnya sawi di bersihkan dari sisa kotoran tanah yang menempel pada sawi dan memercikkannya dengan air agar sawi tetap segar dan siap dipasarkan. Biasanya pemasarannya dijual dengan sistem ikat dan 
diborong oleh para tengkulak untuk di jual ke Pasar Besar yang ada di Kota Palangka Raya dan sekitarnya.

\section{Produksi Sayuran Sawi}

Jumlah produksi sayuran sawi yang dihasilkan dalam 1 kali tanam di Kelurahan Kalampangan Kecamatan Sabangau Kota Palangka Raya berada dalam tingkatan yang berbeda - beda. Jumlah responden terbesar yaitu 13 petani $(43,34 \%)$ menghasilkan produksi sawi dengan kisaran jumlah dari 251 ikat sampai 300 ikat dalam 1 kali panen per bedengan. Sedangkan untuk jumlah responden terkecil yaitu 7 petani $(23,33 \%)$ menghasilkan produksi sawi dengan kisaran 200 ikat sampai 250 ikat dalam 1 kali panen per bedengan, angka ini diperoleh dari hasil jumlah produksi petani sayuran sawi di Kelurahan Kalampangan dengan rata-rata jumlah produksi sayuran sawi sebesar 298 ikat/petani/bedengan. Diharapkan petani Kelurahan Kalampangan dapat menghasilkan produksi sayuran sawi yang lebih tinggi lagi dengan menyeimbangkan penggunaan luas lahan dan standar budidaya yang baik karena sawi adalah sayuran yang selalu dikonsumsi masyarakat.

\section{Luas Lahan}

Jumlah penggunaan luas lahan untuk usahatani sayuran sawi di Kelurahan Kalampangan Kecamatan Sabangau Kota Palangka Raya menunjukkan luas lahan yang lebih sedikit berkisar $20 \mathrm{~m}^{2}-30 \mathrm{~m}^{2}$ digunakan petani berjumlah 20 orang $(66,67 \%)$ kemudian untuk luas lahan yang paling besar kisaran $41 \mathrm{~m}^{2}-50 \mathrm{~m}^{2}$ digunakan petani berjumlah 4 orang
$(13,33 \%)$ dan untuk luas lahan yang kisaran nya $31 \mathrm{~m}^{2}-40 \mathrm{~m}^{2}$ digunakan petani berjumlah 6 orang $(20,00 \%)$. Rata-rata luas lahan yang terdapat di Kelurahan Kalampangan yang diperoleh dari 30 responden petani sayuran sawi adalah 30 $\mathrm{m}^{2}$ dengan tiap bedengan berisi 5-10 bedeng dan jarak tanam yang berbeda-beda yaitu $10 \times 20 \mathrm{~cm}-25 \times 30 \mathrm{~cm}$. Tiap bedengan rata-rata petani menghasilkan 298 ikat, dengan demikian dapat menunjukkan bahwa dalam penggunaan luas lahan sudah cukup optimal dan kemungkinan petani untuk menambah luas lahan dapat meningkatkan produksi sayuran sawi.

\section{Penggunaan Benih}

Jumlah benih (gram) yang digunakan untuk memproduksi sayuran sawi di Kelurahan Kalampangan untuk 1 kali tanam adalah 100 gr, 50 gr dan 25 gr. Untuk benih yang 100 gram berjumlah 1 responden $(3,33 \%)$, kemudian benih yang 50 gram berjumlah 6 responden $(20,00 \%)$ dan untuk benih yang 25 gram sebanyak 23 responden $(76,77 \%)$. Rata-rata untuk luas lahan $30 \mathrm{~m}^{2}$ petani menggunakan 32,50 gram benih sawi dimana hasil ini di dapat dari responden petani di Kelurahan Kalampangan.

\section{Analisis Penerimaan, Biaya dan Pendapatan Usahatani Sayuran Sawi di Kelurahan Kalampangan}

Penerimaan, biaya dan pendapatan dari 30 petani yang dijadikan sampel tersebut dapat di lihat pada penjelasan Tabel 1 sebagai berikut : 
Tabel 1. Perincian Rata-Rata Penerimaan, Biaya dan Pendapatan Usahatani Sayuran Sawi di Kelurahan Kalampangan Kecamatan Sabangau Kota Palangka Raya Tahun 2019 untuk 1 kali tanam

\begin{tabular}{|c|c|c|c|}
\hline No & Uraian & $\begin{array}{c}\text { Rata - rata } \\
\text { Responden } \\
(\mathbf{R p}) \\
\end{array}$ & $\begin{array}{c}\text { Persentase } \\
(\%)\end{array}$ \\
\hline 1 & $\begin{array}{l}\text { Penerimaan } \\
\text { a. Produksi Sayuran Sawi } \\
\quad \text { (Ikat/bedengan) } \\
\text { b. Harga Sayuran Sawi (Rp) } \\
\text { Total Penerimaan (Total Revenue) = } \\
\text { (a } \mathbf{x} \text { b) }\end{array}$ & $\begin{array}{r}298 \\
4.200 \\
\\
\mathbf{1 . 2 4 9 . 7 5 0}\end{array}$ & \\
\hline 2 & $\begin{array}{l}\text { Biaya } \\
\text { a. Biaya Tetap (Fixed Cost) } \\
\text { 1. Biaya Penyusutan Alat } \\
\text { - Pisau } \\
\text { - Cangkul } \\
\text { - Garuk/Garpu } \\
\text { - Handsprayer } \\
\text { - Selang } \\
\text { - Hitachi/Mesin Pompa Air } \\
\\
\text { Total Biaya Tetap (a) }\end{array}$ & $\begin{array}{r}3.493 \\
8.267 \\
6.000 \\
33.067 \\
36.800 \\
240.000 \\
\mathbf{3 2 7 . 6 2 7}\end{array}$ & $\begin{array}{r}0,71 \\
1,67 \\
1,21 \\
6,68 \\
7,43 \\
48,46 \\
\mathbf{6 6 , 1 5}\end{array}$ \\
\hline & $\begin{array}{l}\text { b. Biaya Variabel (Variable Cost) } \\
\text { 1. Benih } \\
\text { 2. Pupuk } \\
\text { - Urea } \\
\text { - NPK Phonska } \\
\text { - NPK Mutiara } \\
\text { 3. Pestisida } \\
\text { 4. } \text { Tenaga Kerja } \\
\text { Total Biaya Variabel (b) }\end{array}$ & $\begin{array}{r}27.200 \\
\\
6.617 \\
9.117 \\
30.667 \\
65.667 \\
23.333 \\
\mathbf{1 6 2 . 6 0 0}\end{array}$ & $\begin{array}{r}5,49 \\
\\
1,35 \\
1,84 \\
6,20 \\
14,27 \\
4,71 \\
\mathbf{3 3 , 8 4} \\
\mathbf{1 0 0 , 0 0}\end{array}$ \\
\hline & Total Biaya $($ Total Cost $)=(\mathbf{a}+\mathbf{b})$ & 495.227 & \\
\hline 3 & $\begin{array}{l}\text { Pendapatan } \\
\text { 1. Total Penerimaan } \\
\text { 2. Total Biaya }\end{array}$ & $\begin{array}{r}1.249 .750 \\
495.227\end{array}$ & \\
\hline & Total Pendapatan $($ Income $)=(1-2)$ & 754.523 & \\
\hline
\end{tabular}

Sumber : Data Primer yang diolah, 2020

Berdasarkan Tabel 1 diketahui bahwa jumlah produksi sayuran sawi dalam satu kali tanam rata-rata sebesar $298 \mathrm{ikat} / \mathrm{bedengan}$ dengan rata-rata harga sawi Rp 4.200/ikat sehingga rata-rata penerimaan yang dikelola oleh petani memperoleh penerimaan sebesar Rp 1.249.750.

Sementara untuk biaya yang dikeluarkan oleh petani di Kelurahan 
Kalampangan yaitu terdiri dari biaya tetap dan biaya variabel. Biaya tetap usahatani sayuran sawi meliputi biaya penyusutan alat seperti pisau Rp $3.493(0,71 \%)$, cangkul sebesar $\mathrm{Rp}$ $8.267(1,69 \%)$, garuk/garpu sebesar Rp $6.000 \quad(1,22 \%)$, handsprayer sebesar Rp 33.067 (6,74\%), selang sebesar Rp 36.800 (7,50\%), hitachi sebesar Rp $240.000 \quad$ (48,95\%). Sedangkan untuk biaya variabel terdiri dari biaya benih rata-rata nya sebesar Rp 27.200 (5,54\%), biaya pupuk urea Rp 6.617 (1,35\%), pupuk NPK Phonska Rp 9.117 (1,85\%), pupuk NPK Mutiara Rp 30.667 (6,25\%), biaya pestisida sebesar Rp $65.667(13,40 \%)$ dan biaya untuk tenaga kerja sebesar Rp23.333 $(4,76 \%)$.

Besar kecilnya penerimaan usahatani tergantung dari harga komoditas dan jumlah produksi yang diperoleh. Jika jumlah produksi meningkat dengan asumsi bahwa harga komoditas tetap maka penerimaan akan meningkat. Besarnya penerimaan yang diperoleh para petani yaitu sebesar Rp 37.492.500 dengan rata-rata memperoleh penerimaan untuk 1 kali tanam sebesar Rp 1.249.750/petani.

Pendapatan yang diperoleh responden/petani dalam usahatani sayuran sawi yaitu selisih dari total penerimaan dengan total biaya yang dikeluarkan dalam usahatani sayuran sawi. Total Penerimaan diketahui sebesar Rp 37.492.500 dengan ratarata $\mathrm{Rp}$ 1.249.750/petani sedangkan biaya totalnya sebesar Rp 14.856 .800 dengan rata-rata biaya total sebesar Rp 495.227/petani sehingga diperoleh pendapatan sebesar Rp 22.635.700 dengan rata-rata besarnya pendapatan untuk 1 kali tanam dan 1 kali panen sebesar Rp 754.523/petani dengan

$$
\begin{aligned}
& \text { perhitungan sebagai berikut } \\
& \text { (Lampiran 12) : } \\
& \begin{aligned}
I \quad=T R-T C \\
\quad=\operatorname{Rp~} 1.249 .750-\mathrm{Rp} 495.227 \\
=\operatorname{Rp~} 754.523
\end{aligned}
\end{aligned}
$$

\section{Tingkat Efisiensi Usahatani Sayuran Sawi di Kelurahan Kalampangan}

Hasil analisis Tingkat efisiensi tersebut sebagaimana terlihat pada Tabel 2 sebagai berikut :

Tabel 2. Rata - Rata Penerimaan, Biaya dan efisiensi Usahatani Sayuran Sawi untuk 1 kali tanam di Kelurahan Kalampangan Kecamatan Sabangau Kota Palangka Raya Tahun 2019

\begin{tabular}{lr}
\hline \multicolumn{1}{c}{ Uraian } & Rata - Rata \\
\hline Total Penerimaan & 1.249 .750 \\
$(T R)(\mathrm{Rp})$ & 495.227 \\
Total Biaya $(T C)$ & \\
$(\mathrm{Rp})$ & $\mathbf{2 , 5 2}$ \\
Tingkat Efisiensi & \\
$(\boldsymbol{R} / \boldsymbol{C}$ Ratio) & \\
\hline
\end{tabular}

Sumber : Data Primer yang diolah, 2020

Berdasarkan Tabel 2 dapat di lihat bahwa rata-rata penerimaan petani sayuran sawi adalah sebesar Rp 1.249.750/petani dibagi dengan ratarata biaya total sebesar $\mathrm{Rp}$ 495.227/petani sehingga diperoleh $R C R$ sebesar 2,52 artinya untuk setiap $\mathrm{Rp} 1,00$ biaya yang dikeluarkan oleh petani diperoleh penerimaan sebesar $\mathrm{Rp}$ 2,52. Nilai $R C R$ lebih dari 1 sehingga usahatani sayuran sawi yang diusahakan petani di Kelurahan Kalampangan Kecamatan Sabangau Kota Palangka Raya sudah efisien atau menguntungkan dan layak untuk diusahakan kembali.

KESIMPULAN DAN SARAN Kesimpulan 
Berdasarkan hasil dan penelitian pembahsan yang dilakukan di RW. 03 di Kelurahan Kalampangan Kecamatan Sabangau Kota Palangka Raya, maka dapat di ambil beberapa kesimpulan antara lain sebagai berikut :

1. Tingkat keragaan usahatani sayuran sawi yang dilaksanakan di Kelurahan Kalampangan Kecamatan Sabangau Kota Palangka Raya secara teknis bercocok tanam sudah cukup baik. Pengaturan jarak tanam yang belum sesuai dengan standar budidaya tanaman sayuran sawi dan perlu diterapkan oleh petani untuk pengaturan jarak tanam yang ideal yaitu $50 \times 60 \mathrm{~cm}$ dalam bedengan. Dengan demikian penggunaan pengaturan jarak tanam yang ideal dapat meningkatkan produksi yang optimal.

2. Tingkat penerimaan, biaya dan pendapatan usahatani sayuran sawi di Kelurahan Kalampangan Kecamatan Sabangau Kota Palangka Raya diketahui sebesar :

a. Tingkat penerimaan $\mathrm{Rp}$ 37.492.500/ $892 \mathrm{~m}^{2}$ dengan rata-rata total penerimaan $\mathrm{Rp}$ $1.249 .750 /$ petani $/ 30 \mathrm{~m}^{2}$

b. Tingkat total biayanya $\mathrm{Rp}$ 14.856.800 dengan rata-rata total biaya sebesar $\mathrm{Rp}$ 495.227/petani.

c. Tingkat Pendapatan yang diperoleh responden/petani yaitu sebesar Rp 22.635.700 dengan rata-rata pendapatan untuk 1 kali tanam dan 1 kali panen dalam 1 bedengan sebesar Rp 754.523/petani/30 $\mathrm{m}^{2}$, sehingga usahatani sayuran sawi di Kelurahan Kalampangan menguntungkan untuk petani sayuran sawi, hal ini dapat dilihat dari penerimaan yang lebih besar dibandingkan dengan biaya yang dikeluarkan untuk usahatani sawi caisim.

3. Tingkat efisiensi usahatani sayuran sawi di Kelurahan Kalampangan adalah efisien, dimana nilai $R / C$ ratio nya sebesar 2,52 artinya untuk setiap Rp 1,00 biaya yang dikeluarkan oleh petani akan menghasilkan penerimaan sebesar $\mathrm{Rp} 2,52$. Nilai $R / C$ ratio lebih dari 1 (satu) sehingga usahatani sayuran sawi yang diusahakan petani di Kelurahan Kalampangan Kecamatan Sabangau Kota Palangka Raya sudah efisien atau menguntungkan dan layak untuk diusahakan kembali.

\section{Saran}

Berdasarkan kesimpulan diatas maka disarankan :

1. Sebaiknya penyuluh menerapkan teknis budidaya kepada petani sayuran sawi dalam mengatur penggunaan jarak tanam agar populasi, pertumbuhan dan perkembangan tanaman sayuran sawi caisim lebih optimal sehingga menghasilkan produksi yang optimal.

2. Upaya peningkatan pendapatan petani di Kelurahan Kalampangan dari Pemerintah melalui penyuluhan yang lebih intensif dan lebih berperan aktif dalam mengawasi perkembangan harga jual sayuran sawi di pasar, karena sering terjadi fluktuasi harga yang tidak menentu. Jika harga jual sayuran sawi di pasar berada pada posisi normal bahkan mencapai harga jual yang tinggi maka 
pendapatan yang diperoleh petani juga akan tinggi.

3. Selain itu petani dalam menggunakan sarana produksi seperti pupuk dan pestisida agar lebih efisien sehingga tingkat pendapatan usahatani yang diperoleh akan menjadi lebih tinggi. Hal ini dikarenakan biaya sarana produksi seperti pupuk dan pestisida merupakan biaya yang paling besar yang harus dikeluarkan petani dalam menjalankan usahataninya.

\section{DAFTAR PUSTAKA}

Aruan, Wanda, Iskandarini dan Mozart. 2017. Analisis Finansial Usahatani Sawi (Studi Kasus : Kelurahan Terjun Kecamatan Medan Marelan). Program Studi Agribisnis Fakultas Pertanian Universitas Sumatera Utara. Medan.

Balai Penyuluhan Pertanian Kalampangan. 2016. Programa Penyuluhan 2016. Badan Pelaksana Penyuluhan Pertanian, Perikanan, dan Kehutanan, Kelurahan Kalampangan, Kecamatan Sabangau. Kota Palangka Raya.

Misri. 2013. Analisis Pendapatan Usaha Tani Sawi Di Desa Purwosari Kecamatan Kuala Pesisir Kabupaten Nagan Raya. Program Studi Agribisnis Fakultas Pertanian Universitas Teuku Umar Meulaboh. Aceh Barat.

Prasetya, P. 2006. Handout Ilmu Usahatani. Fakultar Pertanian, Universitas Sebelas Maret. Surakarta.
Putri, Utami. 2016. Kiat Sukses Usaha Budidaya Sawi. Lumenta Publishing. Yogyakarta.

Singarimbun, Masri dan Sofian Effendi. 2008. Metode Penelitian Survei. LP3ES. Jakarta.

Soekartawi. 2006. Analisis Usahatani. Penerbit Universitas Indonesia UI. Press. Jakarta.

Sugiyono. 2013. Metode Penelitian Kombinasi (Mixed Methods). CV. Alfabeta. Bandung.

Suratiyah, K. 2009. Ilmu Usahatani. Penebar Swadaya. Jakarta.

Zulkarnain. 2014. Dasar - Dasar Hortikultura. Bumi aksara. Jakarta.

Zulkarnain. 2013. Budidaya Sayuran Tropis. PT. Bumi Aksara. Jakarta. 